\title{
A ADOÇÃO E SUA NOVA LEI
}

\author{
Altino P. Soares Pereira \\ Professor Catedrático de Direito Civil da Facul- \\ dade de Direito da Universidade do Paraná
}

Os institutos jurídicos, em sua evolução, modificam-se sensìvelmente.

E 0 que vemos no estudo da adoção.

Entre os povos antigos, era instituto de direito público, não se podendo desconhecer o grande interêsse que existia em dar sucessor aos que não tinham filhos pela natureza. 0 fator religioso exerceu decisiva influência para sua instituição, pois o filho adotivo foi o continuador do culto doméstico, das cerimônias fúnebres.

Entre romanos, gregos e indús múita solenidade exigia 0 ato da adoção, o que faz denotar sua utilidade e elevado alcance. Na velha Roma, teve a imponência de cerimônia pública, em comícios. A chancela do príncipe ou do magistrado, no direito justineaneo, atestou sua grande revelância. A adoção era um meio de perpetuar-se a família e propugnar o equilíbrio e prosperidade da Cidade.

As transformações sociais, contudo, não permitiram que ela se mantivesse em destaque, como na antiguidade.

Assim, nas Ordenações do Reino (L. 2. ${ }^{\circ}$, Tit. 35, § 12) e em nosso Direito Anterior ao Código Civil, o instituto não despertou grande interêsse. Simples remédio à esterilidade, consôlo dos que não tinham filhos, não constituiu o móvel da preocupação dos legisladores. A Consolidação de Teixeira de Frei- 
tas (art. 217) refere-se à sua confirmação; a de Carlos de Carvalho consagra-lhe um capítulo em que poucos direitos se reconhecem aos filhos adotivos (arts. $1.635-1.640$ ).

Entendia o grande Lafayete que a adoção estava em desuso, razão por que da mesma não se devia cuidar.

Quando se discutiu o Projeto do Código Civil, dividiramse as opiniões. Alguns não reconheciam suas vantagens, enquanto muitos lhes assinalavam inúmeras virtudes.

A verdade, porém, é que, no regime do Código Civil, produziu a adoção bons frutos e, de tal forma, a experiência realizada não desaconselha, antes nos concita a lutar pela sua manutenção.

Bem distantes, no tempo, estamos das repúblicas grega e romana, mas a alteração sofrida pelos nossos costumes não poderia ser de molde a erradicar do homem, não pròpriamente o desejo de perpetuar-se mas a satisfação de poder chamar alguém pelo nome de filho.

Com o advento da Lei n. 3.133, de 8 de maio de 1957, não mais acalentamos dúvidas sôbre a existência da adoção, do seu uso por muitas pessoas, da sua razão de ser. Se inexistissem motivos para o seu aparecimento, a sua elaboração não teria alimentado as atividades do Legislativo.

Realmente não se trata de um instituto obsoleto. A êste respeito, deixamos de acompanhar o preclaro Lafayete e não

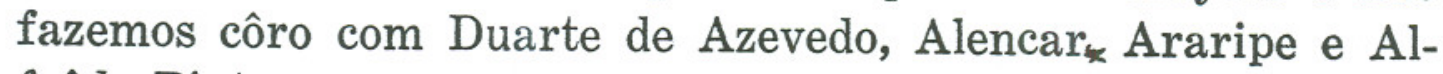
frêdo Pinto.

O instituto está vivo e talvez robustecido com a admissão de um novo fundamento que se veio juntar ao seu fundamento principal. Hoje, êle não se destina apenas a perpetuar nomes de famílias e patrimônios e a manter acêsa a chama dos sacra privata. Com altruística base, êle prodigaliza vantagens aos que precisam desenvolver-se no ambiente da família, que não têm, e, nesse propósito, realiza verdadeiro ajustamento social para certas pessoas, dando-lhes pais e irmãos.

Em outra ocasião, invocando o Prof. Cirilo Pavon, da Faculdade de Direito da Universidade de Buenos Aires, dissemos 
que o problema da adoção é de suma transcedência e de elevado alcance social. Demonstrámos, então, a necessidade de tornar mais brandas as exigências de nosso Código Civil a seu respeito, o que possibilitaria ampliar sua aplicação e, assim, difundir maior soma de benefícios na sociedade.

Veio a Lei n. 3.133 de 8 de maio de 1957, que provocou reações diversas, pelo fato de ter rompido a tradição, não só de nosso direito mas do da maioria dos povos civilizados.

Com efeito, se perlustrarmos as disposições legais atinentes ao assuntos, vigentes em inúmeros países, verificaremos que a adoção é permitida às pessoas, sem prole legítima ou legitimada e, de tal forma, é um meio de preencher a lacuna deixada pela natureza. E, se redunda em benefício dos adotados, continua a ser o consôlo dos adotantes.

É o que vemos no art. 291 do novo Código Civil Italiano, que não se distanciou muito do nosso, em seu art. 368 .

Foi isto, justamente, o que a nova Lei brasileira alterou.

Em sua nova redação, não mais exige o art. 368 do Código que, para adotar, não tenha o adotante prole legítima ou legitimada. Nota-se apenas que o $\S$ único, que se lhe acrescentou, permite a adoção aos casados sòmente após o decurso de cinco anos da realização do casamento.

Dispunha o Código Civil:

"Só os maiores de cincoenta anos, sem prole legítima, ou legitimada, podem adotar".

Esta é a redação dada pela Lei 3.133:

"Só os maiores de 30 (trinta) anos podem adotar.

$\S$ único. Ninguém pode adotar, sendo casado, senão decorridos 5 (cinco) anos após o casamento".

A restrição contida nêste parágrafo evidentemente colima cbviar aos inconvenientes da supressão da natalidade. De fato, é inadmissível que o legislador se preocupe em dar prole àqueles que se recusam a aceitá-la da própria natureza. Esta conclusão está reafirmada pelo art. 377 , nova redação da mesma Lei, que permite a adoção às pessoas que têm filhos. Se outra 
fôsse a razão impeditiva do $\S$ único, e. g., abroquelar os interêsses de uma prole futura, não se possibilitaria a adoção aos que possuem prole, como está no referido artigo da Lei.

É verdade que a relação de adoção, nêste caso, não envolverá a de sucessão hereditária.

Sensível foi a alteração feito no instituto, que passou a ter mais de um fundamento.

Em face da nova Lei, nem sempre surge o adotado como consôlo para o adotante, mas o altruismo dêste é que o consola e não lhe poupa a comoção ao ver que um estranho lhe oferece a mesa, lhe extende o agasalho e, muito mais do que tudo isso, procura ajustá-lo na sociedade em que vive, aconchegando-o na intimidade dos seus.

0 instituto da adoção foi, pois, reestruturado. Tanto podem adotar aquêles que não têm filhos pela natureza como os que os têm. Nêste último caso, deriva a adoção do novo fundamento aceito, de natureza assistêncial, e como já se disse, não envolve a relação de sucessão hereditária.

0 direito de sucessão em aprêço reconhecido em lei para os filhos adotivos é decorrência de sua equiparação aos filhos legítimos e legitimados.

Embora se não confundam o princípio da adoção e o da sucessão hereditária, inegàvelmente 0 Direito das Sucessões sempre se socorre do Direito de Família para estabelecer a ordem de vocação hereditária e todos os direitos dos herdeiros, entre os quais, é óbvio, estão os filhos do sucedendo. Para êstes, estabelece algumas distinções quanto à espécie de filiação.

Aí está o motivo por que os filhos adotivos de pessoas que possuem prole não têm direito de suceder hereditàriamente os adotantes. Não vindo tais filhos preencher uma lacuna deixada nos lares pela natureza, não ficam os mesmos perfeitamente equiparados aos filhos legítimos e legitimados, como sucede com os adotivos de pessoas que não têm filhos. Nêste caso, outro é o fundamento da adoção.

O Lei n. 3.133, ao dar nova redação ao art. 377, excluiu, expressamente, o efeito de sucessão hereditária, nos casos que 
especifica, porque a disposição aludida não está mais em consonância com o sistema do Código. Sem essa ressalva, muitas dificuldades poderiam surgir, na prática, em razão do desfalque a que ficariam sujeitas as legítimas dos outros filhos. 0 desassossêgo dêstes precisava ser evitado.

Na elaboração dos Códigos, comuns são as ressalvas desta natureza sempre que se verifica uma falha no sistema vigente. E, no caso, a mesma ocorreu por ter a Lei 3.133, permitido a adoção às pessoas com prole.

Segundo o Código Civil, duas são as situações dos filhos adotivos: ou recolhem tôda a herança, por serem os únicos filhos, ou metade do que herdarem os legítimos, se os existirem supervenientes à adoção (art. 1605 e $\S 2 .^{\circ}$ ). Nada mais.

Com o advento da Lei 3.133, entenderam muitos que o preceito do art. 377 do Código, nova redação, abrange os filhos adotivos que concorrem com legítimos supervenientes à adoção.

Tal inferência, porém, não se justifica em face dos princípios vigentes.

Para que o preceito do art. $1.605, \S 2 .^{\circ}$, do Código Civil, não mais vigorasse, seria necessário que o mesmo se tornasse, de todo, inconciliável com a nova lei, visto que nenhuma expressão desta se lhe opõe, claramente.

No caso em estudo, derrogado ficou o art. 368 do Código Civil, porque, hoje, se admite que pessoas com prole legítima, legitimada ou reconhecida possam adotar. Isto é inconciliável com o que dispunha o Código.

Não acontece o mesmo com o $\S 2 .^{\circ}$ do art. 1.605 , a que não se refere a Lei 3.133. Sendo propósito do legislador possibilitar a adoção mesmo aos que já têm filhos, excluindo-se, em tais casos, a relação de sucessão hereditária, não se pode inferir daí que devam também ficar privados de herança os filhos adotivos pelo fato de sobrevir prole legítima, legitimada ou reconhecida aos adotantes. Esta ilação não nos parece lógica.

Uma hipótese não se confunde com a outra. A pessoa a que sobrevêm filhos legítimos, legitímados ou reconhecidos, de- 
pois de ter feito uso da adoção, não se acha no mesmo caso da que, tendo filhos, ainda assim recorre à adoção. Não se pode, por êste motivo, suprimir o direito de suceder hereditàriamente, dos filhos adotivos que concorrem com legítimos supervenientes à adoção ( $§ 2 .^{\circ}$, art. 1.605 citado $)$.

É que o instituto foi alterado apenas parcialmente. A adoção, como remédio à esterilidade, continua a existir e não é possível negar seus normais efeitos.

Carlos Maximiliano, refletidamente, afirma:

"Pode ser promulgada nova lei sôbre o mesmo assunto sem ficar tàcitamente ab-rogada a anterior: ou a última restringe apenas o campo de aplicação da antiga; ou, ao contrário, dilata-o, estende-o a casos novos; é possível até transformar a determinação especial em regra geral. Em suma: a incompatibilidade implícita entre duas expressões de Direito não se presume; na dúvida, se considerará uma norma conciliável com a outra".

Hermenêutica e Aplicação do Direito, pág. 428.

Foi o que aconteceu com a adoção. A Lei criou novos casos, mas, pelos motivos já expostos, lhes deu diverso tratamento no que tange ao direito de suceder.

Em tais condições, não se pode concluir que as normas atinentes a êsses casos devam aplicar-se àqueles que se achavam perfeitamente disciplinados e não constituem o objetivo da alteração feita no instituto. E não importa que na Lei 3.133 não haja uma expressão esclarecedora a êsse respeito.

Normal é que não se reconheça o direito de sucessão hereditária aos filhos adotivos de pessoas que, ao adotarem, já possuiam prole legítima, legitimada ou reconhecida. 0 reconhecimento de tal direito daria ensêjo a que muitos lançassem mão da adoção em detrimento de filhos com os quais se desaviessem. $\mathrm{E}$ na lei não deve encerrar meios que sirvam para sua burla. Não se concebe, por outro lado, que a adoção venha subverter os princípios dos demais institutos da filiaçâo. 
No dizer dos mestres, a adoção, para os que não têm filhos, ̣̂ imagem da filiação legítima. De acôrdo com êsse entendimento, o art. 1.605, de nosso Código estabelece:

"Para os efeitos da sucessão, aos filhos legítimos se equiparam os legitimados, os naturais reconhecidos e os adotivos".

Não é justo que se chame a sucessão pessoa de outra classe, quando existem filhos de uma das mencionadas categorias, na classe dos descendentes.

$0 \S 2 .^{\circ}$ do art. 1.605 transcrito, entretanto, reduz a herança dos adotivos que concorrerem com legítimos supervenientes à adoção. Relativamente a essa redução đle quota hereditária, manifestou-se inconformado o eminente e saudoso Clóvis Bevilaqua (Código Civil, vol. 6.․․ pág. 65).

Tal distinção inexiste no moderno Código Italiano que, para fins sucessórios, equipara aos filhos legítimos, os legitimados e adotivos.

Entre nós, criaram-se duas categorias de filhos adotivos: das pessoas que lançaram mão da adoção, por não possuirem filhos, e das pessoas que à adoção recorreram não obstante já os possuirem. Os adotivos a que se refere o $\$ 2 .^{\circ}$ do art. 1.605 do Código Civil pertencem à primeira categoria e, em tais condicões, não se lhes aplica o que vem disposto no art. 377 comentado, conforme a redação da Lei 3.133. Tal aplicação acarretaria a insegurança do instituto que se destinando a imitar a família legítima não deve prescindir de sua base patrimonial, fator apreciável para seu desenvolvimento.

Como ficou bem explícito, o disposto no aludido art. 377 concerne a uma das inovações da Lei citada. Bem definiu a posição dos filhos adotivos das pessoas com prole legítima, legitimada ou reconhecida.

A Jurisprudência fixará, por certo, os novos contôrnos do instituto e, nessa obra não há de se desviar dos fundamentos básicos que o justificam.

Agora, não se trata de verificar se a nova espécie de adoção é boa ou má. Entende-se, porém, que o art. 377, nova reda- 
ção, evita que constitua a adoção nos casos recentemente admitidos uma fonte exuberante de desarmonia da família. Seu papel verdadeiro é conciliar os legítimos interêsses dos indivíduos e da sociedade.

O já citado Carlos Maximiliano, em seu Direito de Sucessões, vol. $1^{\circ}$, pág. 345, discorrendo sôbre filhos adotivos, afirma:

"Embora menoscabada pelos práticos, merece o louvor dos teóricos a adoção, consôlo dos que não lograram a ventura de engendrar prole, meio de oferecer aos melhores dotados para criar filhos, a oportunidade de serem úteis à sociedade e à infância desvalida, transformando órfãos e abandonados em pessoas bem dotadas, operosas, felizes e úteis".

Dêsse modo, colima a adoção dar prole a quem não a possui e, além disso, vai ao encontro dos mais altos propósitos de solidariedade humana.

Esta é, sem dúvida, a orientação seguida, ùltimamente, pelo nosso direito.

Outras modificações trouxe a Lei n. 3.133, como sejam: a redução do limite mínimo de idade do adotante e da diferença de idade entre êste e o adotado, a exigência expressa de consentimento do adotante, quando capaz, a possibilidade da adoção do nascituro, a ruptura do vínculo da adoção, nos casos de deserdação e o modo pelo qual poderá o adotado formar seus apelidos.

Sempre fomos favoráveis à redução da idade do adotante, pois uma pequena diferença, para menos, não deveria constituir embaraço a um ato, às vêzes, tão necessário e que, só por falta de um requisito essencial, deixava de efetivar-se. Tal redução, entretanto, não devia ter sido tão grande, ao ponto de quase negar uma das finalidades do instituto, que é remediar a esterilidade.

A Lei 3.133 , permitiu a adoção para as pessoas que tenham trinta anos de idade. Aos trinta anos, todavia, inicia-se um período muito fecundo da existência do homem e, porisso, 
nessa idade não é normal que se esvaneça sua esperança de ter filhos pela natureza.

A Lei n. 13.252, de 23 de setembro de 1948, que instituiu a adoção, para menores de 18 anos, na Argentina, exige, para c adotante, a idade mínima de quarenta anos, salvo se tiver mais de oito anos de casado, quando é necessário apenas que seja, pelo menos, dezoito anos mais velho que o adotado.

Nêste particular, a Lei Argentina tem vantagens sôbre a nossa recente Lei 3.133. Os requisitos que impõe às pessoas para poderem adotar, permitem que as relações entre adotantes e adotados dêem uma idéia mais aproximada da família, do que a nossa.

Qutro detalhe que o nosso Código Civil não previu e a que a Lei n. 3.133 , não se refere, é o que diz respeito ao sexo dos adotantes e adotados.

0 Código da Colombia contém interessantes disposições sôbre o assunto.

Declara seu art. 273 :

“A adoção não pode ter lugar senão entre pessoas do mesmo sexo; o pai adotante deve sê-lo de um varão e a mãe adotante de, uma nuulher".

E seu art. 275 estabeleć:

"Os cônjuges podem adotar conjuntamente, e nêste único caso poderá fazer-se a adoção indistintamente em favor de pessoas de um ou de outro sexo".

E bem verdade que tais preceitos constituem justa compensação aos inconvenientes da adoção por pessoas que contam apenas vinte e um anos, como permite o art. 271 do referido Código.

Não obstante isto, mesmo nos casos em que tenham os adotantes muito mais idade, não deixam de ter alcance os dispositivos aludidos, pois não deve a adoção jamais acobertar a aproximação de pessoas que não vivem como pais e filhos.

A Lei 3.133 estendeu a adocão ao nascituro. Possibilitou, por êsse meio, uma solução condigna para os que viriam ao 
mundo sem o estado que todos desejam ter. Não quer isto dizer que o instituto só traga benefícios para nascituros em tal situacão, mas para êles, sem dúvida, tem maior interêsse.

As demais inovações da lei comentada têm em vista ampliar a disciplina da adoção, e. g. o que diz respeito ao consentimento do adotado, a formação de seus apelidos e a ruptura do vínculo estabelecido entre êle e o adotante.

No propósito de melhorar o instituto, muito poderia fazer-se através de um estudo especializado da matéria em exame.

O novo diploma legal não se reveste dos requisitos indispensáveis da técnica, nem se submeteu ao rigor necessário para integrar um sistema jurídico. Mas, se por êsse lado não merece expressões encomiásticas e, até, tem sofrido crítica severa, não se lhe pode negar o mérito de procurar corresponder à realidade social hodierna.

Ademais, com a Lei 3.133 , iremos fazer mais um teste da eficiência da adoção. 